\title{
Start-up of a UASB effluent treatment plant on distillery wastewater
}

\author{
Bileen Wolmarans* and Gideon H de Villiers \\ Water Utilisation Division, Department Chemical Engineering, University of Pretoria, Pretoria 0001, South Africa
}

\begin{abstract}
Distillery effluent is a contaminated stream with COD values of up to $30000 \mathrm{mg} / \ell$ and low $\mathrm{pH}$ values of between 3 and 4 . The anaerobic biological treatment of distillery effluents is widely applied as an effective step in removing more than $90 \%$ of the COD in the effluent stream. This paper reports on the seasonal operation of a UASB treatment plant treating a distillery wastewater stream with particular focus on seasonal start-up conditions after the first process commissioning. The start-up period was typically one week before process stability could be achieved. It is recommended that the loading rate to the plant be controlled between 4 and $8 \mathrm{~kg} \mathrm{COD} / \mathrm{m}^{3} \cdot \mathrm{d}$ until the process is stable and COD removal efficiencies remain, on average, higher than $90 \%$. After the start-up period the loading rate applied (4 to $18 \mathrm{~kg} \mathrm{COD} / \mathrm{m}^{3} \mathrm{~d}$ ) did not significantly affect the COD removal efficiency of the plant. High removal efficiencies of higher than $90 \%$ were achieved and stop-start operation of the UASB process posed no problem for treatment.
\end{abstract}

\section{Introduction}

A distillery in Wellington in South Africa uses grape wine feedstock (during the grape season) that is fermented and then distilled to separate the alcohol from the fermented liquid. The resulting effluent stream from the process is highly polluted with a Chemical Oxygen Demand (COD) of 20000 to $30000 \mathrm{mg} / \ell$ and a low $\mathrm{pH}$ of between 3 and 4 . These values are comparable with other grape wine based distillery effluents with COD values of between 22000 and $48000 \mathrm{mg} / \ell$ reported by Driessen et al. (1994). Effluent from a wine distillery consists primarily of organic acids with a high soluble biodegradable COD fraction of $98 \%$ (Moosbrugger et al., 1993). In Table 1 the typical composition of a wine distillery waste with respect to organic acids is provided.

To pre-treat this effluent, the winery installed an upflow anaerobic sludge blanket (UASB) process in 1994 to reduce the COD concentration to acceptable levels for discharge to the municipal sewer.

\begin{tabular}{|c|c|}
\hline \multicolumn{2}{|c|}{ TABLE 1 } \\
$\begin{array}{c}\text { Organic acid composition } \\
\text { of wine distillery effluent } \\
\text { (Moosbrugger et al., 1993) }\end{array}$ \\
\hline Tartaric acid & $27 \%$ \\
Malic acid & $8 \%$ \\
Lactic acid & $29 \%$ \\
Succinic acid & $26 \%$ \\
Acetic acid & $10 \%$ \\
\hline
\end{tabular}

Anaerobic biological treatment of high-strength distillery effluent is a proven technology that has been widely applied (Rajeshwari et al., 2000). COD removal efficiencies of more than $90 \%$ and volumetric loading rates of up to $16 \mathrm{~kg} \mathrm{COD} / \mathrm{m}^{3} \cdot \mathrm{d}$, and

* To whom all correspondence should be addressed.

蒕(011)462-4220; fax:(011)462-26267; e-mail: bileen@jhb.biwater.co.za Received 22 December 2000; accepted in revised form 6 September 2001. even higher, is possible. Rajeshwari et al. (2000) reported upper organic loading rates of $16 \mathrm{~kg} \mathrm{COD} / \mathrm{m}^{3} \cdot \mathrm{d}$ for sugar cane distillery effluent, while Driessen et al. (1994) recommended a maximum loading rate of $22 \mathrm{~kg} \mathrm{COD} / \mathrm{m}^{3} \cdot \mathrm{d}$ on a juice distillery effluent in a UASB reactor. A concern, is that biological treatment systems often do not perform well on campaigning industries and long startup periods, in the order of one to two months, is being reported (Austermann-Haun et al. (1994)). When commissioning a reactor for the first time on a particular effluent stream, it is advantageous to utilise sludge from a reactor treating a similar waste. If this is not possible, the sludge will have to be acclimatised to the specific effluent (Hickey et al., 1991). Once the reactor has been commissioned, subsequent start-ups can be performed with the sludge already in the reactor.

In this paper, the results from the monitoring programme that was performed during the last three seasons of operation of the UASB plant will be reviewed. The suitability of UASB technology for campaigning industries and the start-up performance of the pant will be discussed.

\section{Plant and methods}

The full-scale plant was commissioned in 1996, and to ensure a faster start-up, the plant was seeded at a loading rate of $0.55 \mathrm{~kg}$ $\mathrm{COD} / \mathrm{kg}$ VSS with anaerobic granular sludge obtained from a UASB process treating brewery effluent in KwaZulu-Natal, South Africa. The results presented here were obtained from the monitoring performed during the 1998, 1999 and 2000 seasons only, as detailed information is not available prior to 1998 . The distillery operated $24 \mathrm{~h}$ per day during the seasons and the treatment plant was run on a continuous basis while effluent was available. Each year, after the season was completed, the plant was shut down and allowed to stand with effluent and the granular sludge until the following season.

\section{Plant layout}

In Fig. 1, the process flow diagram of the effluent treatment plant is shown. The effluent from the distillery is collected in a balancing 


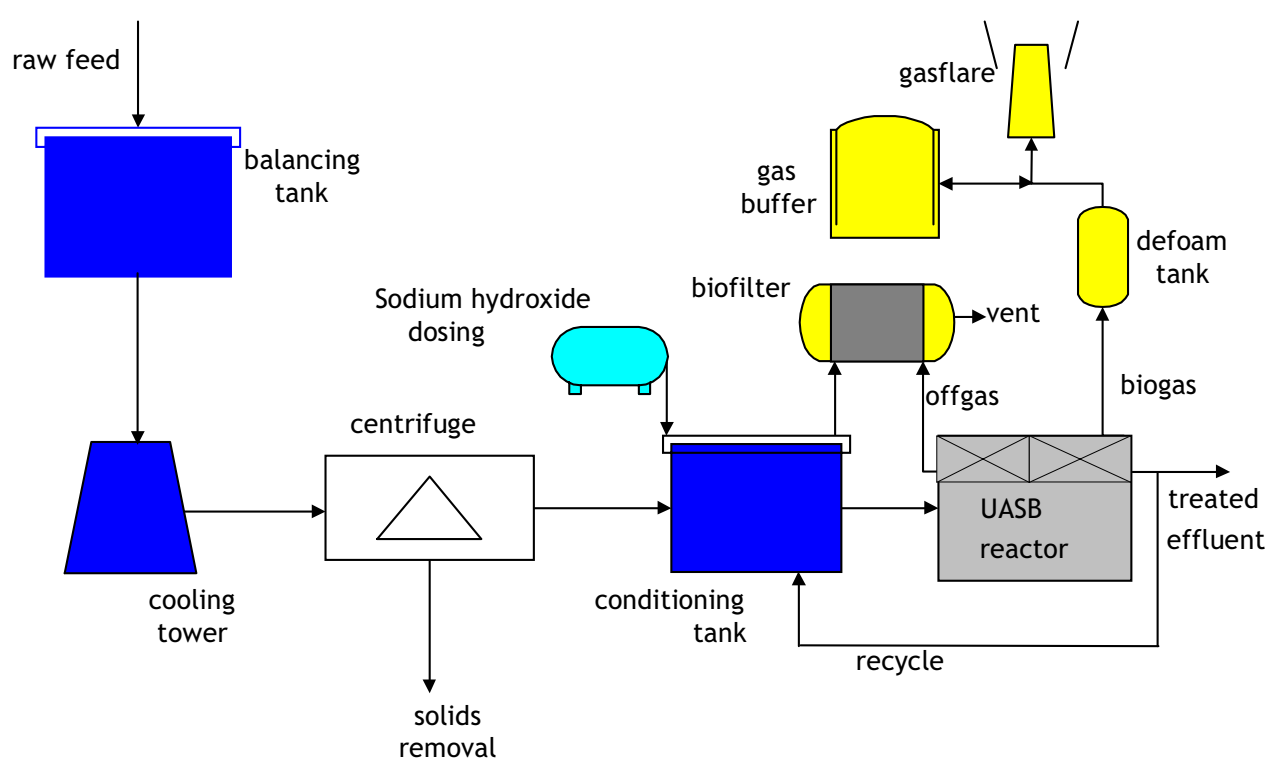

Figure 1

Process flow diagram

tank before it is pumped through a cooling tower to cool the effluent to $37^{\circ} \mathrm{C}$, and then passed through a centrifuge for suspended solids removal. From the centrifuge, the effluent is passed to the conditioning tank where the $\mathrm{pH}$ is corrected. A mixer in the conditioning tank ensures a homogenous feed into the UASB reactor. The $\mathrm{pH}$ is corrected during start-up by the addition of a $45 \%$ sodium hydroxide solution into the conditioning tank to a $\mathrm{pH}$ of 5.8. Once the $\mathrm{pH}$ of the treated effluent increases from the feed $\mathrm{pH}$ to a $\mathrm{pH}$ above 7 , the $\mathrm{pH}$ is corrected by recirculating a portion of the treated effluent into the conditioning tank. This is possible due to the increase in alkalinity of the effluent after anaerobic digestion (Moosbrugger et al., 1993).

Should this recirculation be insufficient, sodium hydroxide can be dosed into the conditioning tank to aid in correcting the $\mathrm{pH}$. The pre-conditioned effluent is then pumped into the bottom of the UASB reactor where the effluent percolates through the granular sludge bed. The overflow from the UASB reactor is collected and disposed to the municipal wastewater treatment plant for further treatment. The nominal retention time in the UASB reactor varied between 4 and $11 \mathrm{~h}$.

The biogas produced in the plant is separated from the effluent and the biomass in three-phase separators at the top of the reactor (patent Paques Natural Solutions BV). The gas is passed through a defoam tank to remove any solids present, and then flared.

The biomass separated from the gas and effluent is retained in the reactor and settles back into the sludge bed. Offgas produced in the conditioning tank and at the surface of the weirs in the UASB reactor is collected and treated through a biofilter prior to being vented to the atmosphere.

\section{Monitoring}

A grab sample of the raw effluent was taken daily at the inlet to the conditioning tank. Another grab sample of the treated water was taken on the discharge line from the UASB reactor to the municipal sewer. The samples were analysed for COD on an unfiltered basis according to Standard Methods (1985).

In Table 2 the time periods when the UASB plant was operating are presented for each of the seasons. As wine feedstock was not continuously available throughout a season, the effluent treatment

\begin{tabular}{|l|l|}
\hline \multicolumn{2}{|c|}{ Period of plant operation } \\
\hline Season & Period of operation \\
\hline 1998 & $\begin{array}{l}\text { 17 February to 30 March } \\
1999\end{array}$ \\
$\begin{array}{l}\text { 3 February to 19 March } \\
\text { 8 April to 16 April } \\
\text { 28 April to 8 May }\end{array}$ \\
2000 & $\begin{array}{l}\text { 2 February to 7 April } \\
\text { 9 May to 18 May }\end{array}$ \\
\hline
\end{tabular}

plant was stopped during the 1999 and 2000 seasons until wine feedstock was available for the distillery and additional effluent was generated.

\section{Evaluation for stable operation and end of start-up}

The start-up period is considered as the period taken for stable operation to be achieved. Van der Westhuizen and Pakkies (1992) indicated that stable operation is achieved when the measured parameters varied less than $10 \%$ after four reactor volume changes.

The performance and start-up of the plant were evaluated against the incoming COD values vs. the treated COD values, and the COD removal efficiency vs. the volumetric loading rate that were applied. Stable operation was assumed when the COD removal efficiency did not vary significantly against the VLR applied and the COD removal efficiency did not vary more than $10 \%$. The volumetric loading rate (VLR) is defined as the kilograms of COD fed to the reactor per cubic metre of total reactor volume per day.

\section{Results and discussion}

\section{COD values}

In Table 3 the raw water composition and the treated water composition are provided for the three seasons. The values 


\begin{tabular}{|l|l|c|c|c|}
\hline \multicolumn{5}{|c|}{ TABLE 3 } \\
\multicolumn{5}{|c|}{$\begin{array}{c}\text { Raw and treated effluent quality from the UASB reactor for } \\
\text { 1998, 1999 and 2000 }\end{array}$} \\
\hline Parameter & Units & 1998 & 1999 & 2000 \\
\hline Raw effluent & & & & \\
COD range & $\mathrm{mg} / \ell$ & 19600 to 34872 & 14900 to 50900 & 12975 to 35775 \\
COD average & $\mathrm{mg} / \ell$ & 27955 & 30706 & 26669 \\
Standard deviation & & 3547 & 6261 & 4120 \\
pH & & 3 to 4 & 3 to 4 & 3 to 4 \\
Temperature & ${ }^{\circ} \mathrm{C}$ & 70 to 80 & 70 to 80 & 70 to 80 \\
\hline Treated effluent & & & & 875 to 9950 \\
COD range & $\mathrm{mg} / \ell$ & 1050 to 5100 & 200 to 9600 & 2814 \\
COD average & $\mathrm{mg} / \ell$ & 2471 & 2038 & 2407 \\
Standard deviation & & 818 & 1306 & 7 to 8 \\
pH & & 7 to 8 & 7 to 8 & 34 to 36 \\
Temperature & ${ }^{\circ} \mathrm{C}$ & 34 to 36 & 34 to 36 & \\
\hline
\end{tabular}

Figure 2

Raw and treated COD values with $C O D$ removal efficiency for 1998

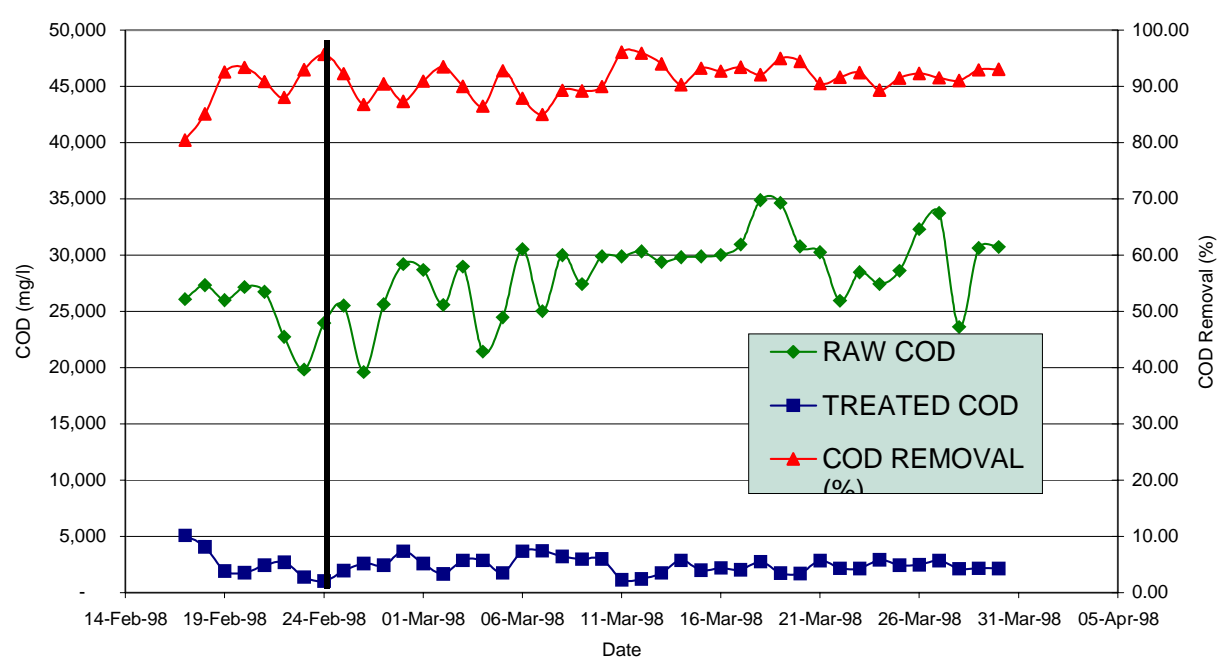

provided are the minimum and maximum values for each of the three seasons from start-up of the plant to final shutdown including COD average values and standard deviation.

The reactor operating temperature was fairly constant between 34 and $36^{\circ} \mathrm{C}$, while the $\mathrm{pH}$ in the feed to the reactor was controlled in the conditioning tank at 5.8. The temperature inside the reactor at start-up was increased from an ambient temperature of approximately $20^{\circ} \mathrm{C}$ to the operating temperature in 2 to $3 \mathrm{~d}$.

In Figs. 2, 3, and 4, the COD of the effluent entering the plant and the treated COD values and COD removal efficiencies are indicated for the years 1998, 1999 and 2000, respectively. A solid vertical line indicates the end of the selected start-up period for each of the seasons. The incoming COD varied considerably throughout the seasons, while after start-up the treated COD values were on average lower than $3000 \mathrm{mg} / \ell$, providing a 90\% COD removal efficiency. This compares well with values of $90 \%$ COD removal efficiencies expected in UASB reactors on distillery effluents reported by Eremektar et al. (1999) and Goodwin and Stuart (1994).

During the 1999 season, the plant was stopped twice for a period of $19 \mathrm{~d}$ and $12 \mathrm{~d}$ respectively (Table 2 and Fig. 3). After the first shutdown the treated COD showed no sign of increase from the first day of feed. However, after the second shutdown and third start-up, the treated COD was much higher than the average 3000 $\mathrm{mg} / \ell$. The high COD value was probably due to a washout of solids from the reactor. The COD removal efficiency remained on average above $90 \%$ after start-up.

During the 2000 season there was one shutdown for $31 \mathrm{~d}$ with no detrimental effect (Table 2 and Fig. 4). Once operational stability was achieved (after $25 \mathrm{~d}$ ), the plant performed according to expected COD removal efficiencies of greater than $90 \%$, and the treated effluent COD values remained stable at below $3000 \mathrm{mg} / \ell$.

\section{Removal efficiencies vs. volumetric loading rates}

The performance of the plant can be related directly to the COD removal efficiencies achieved in the process (Moosbrugger et al., 1993). To understand the removal efficiency of the plant, the loading rates applied to the plant were investigated. In Figs. 5, 6, and 7 the applied VLR is illustrated together with the percentage COD removal for the years 1998, 1999 and 2000 respectively.

It can be noted that during start-up of the plant, the COD removal efficiencies varied correspondingly with the applied VLR. The more erratic the volumetric loading rates applied, the more the performance of the plant varied in terms of \%COD removal. Once the plant had stabilised, the removal efficiencies remained stable 


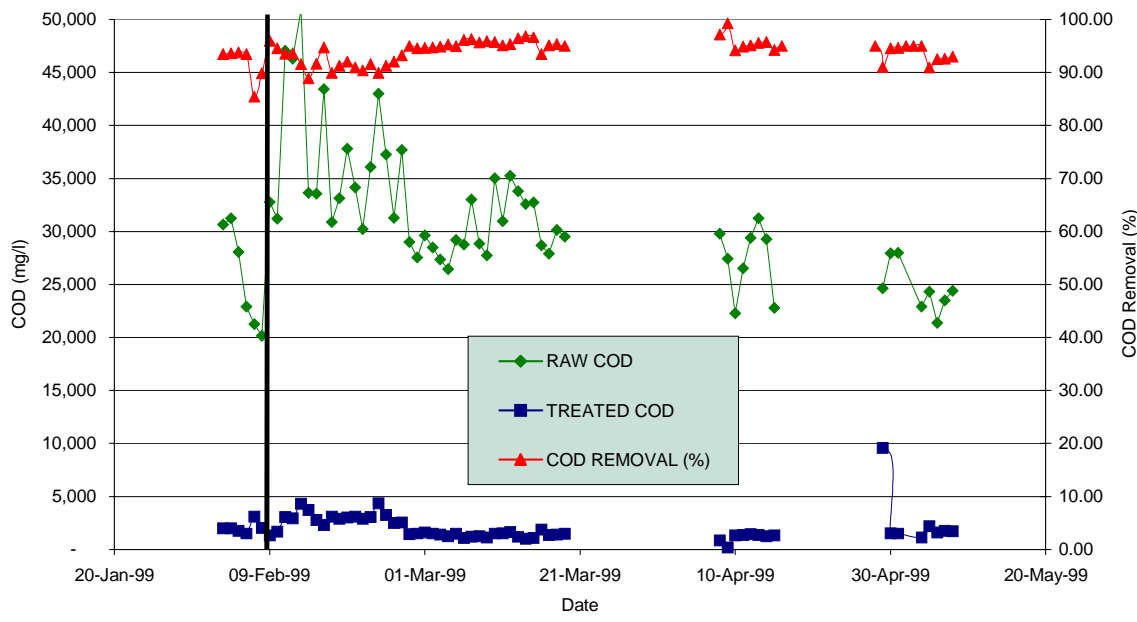

Figure 3

Raw and treated COD values with COD removal efficiency for 1999

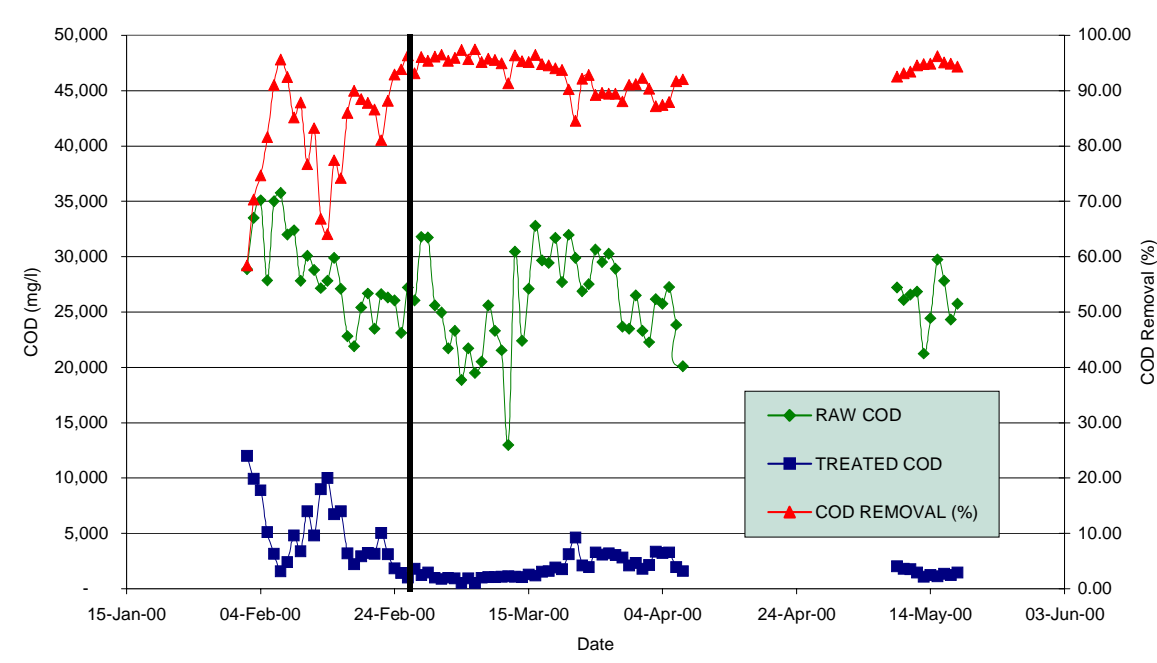

Figure 4

Raw and treated COD values with COD removal efficiency for 2000

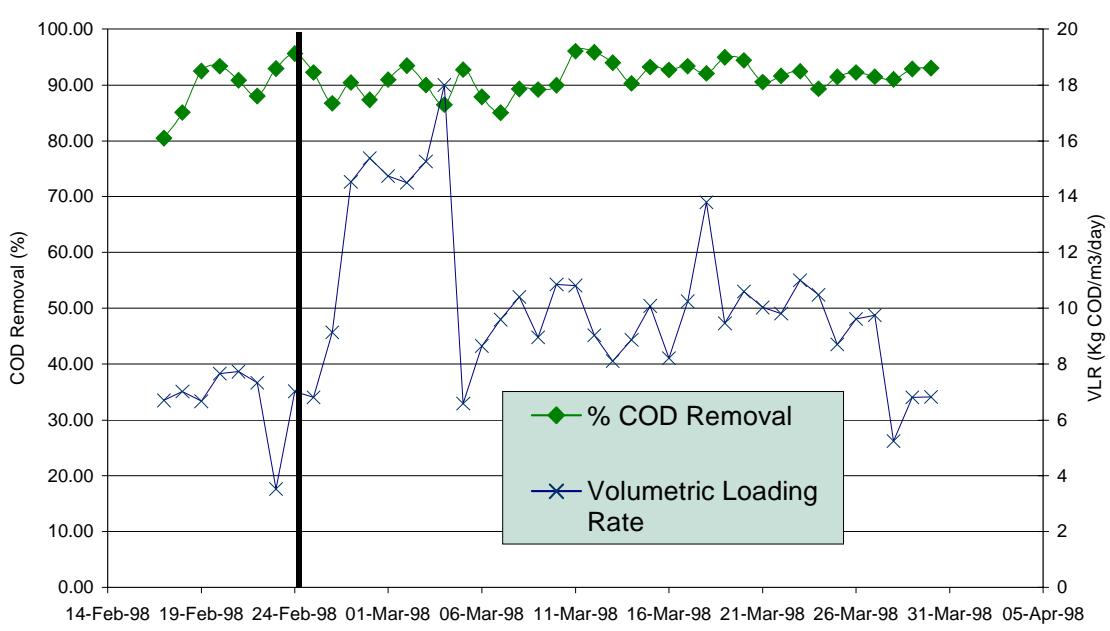

Date

Figure 5

Percentage COD removal efficiency vs. volumetric loading rates for 1998 even with the continued high fluctuations in VLR's. A solid vertical line on Figs. 5, 6 and 7 indicate the end of the selected start-up period for each of the seasons.

The average loading rate applied to the plant during the 1998 season was approximately $10 \mathrm{~kg} \mathrm{COD} / \mathrm{m}^{3} \cdot \mathrm{d}$. This is slightly lower than the design value of $15 \mathrm{~kg} \mathrm{COD} / \mathrm{m}^{3} \cdot \mathrm{d}$, and was due to the lack of availability of wine feedstock.

The results from the 1999 season are shown in Fig. 6. The average applied volumetric loading rate was $10 \mathrm{~kg} \mathrm{COD/}$ $\mathrm{m}^{3} \cdot \mathrm{d}$, which was due to low volumes of effluent availability.

During the 2000 season the first $25 \mathrm{~d}$ showed a period of operational instability with the COD removal efficiency being markedly affected by the applied loading rates. Once the plant had achieved operational stability, the loading rate was increased up to $18 \mathrm{~kg} \mathrm{COD} / \mathrm{m}^{3} \cdot \mathrm{d}$ and the performance of the plant remained stable.

\section{Start-up}

Moosbrugger et al. (1993) recommended that the following parameters be measured during the start-up of an anaerobic reactor: filtered COD, Total Kjeldahl Nitrogen $(\mathrm{TKN})$, inorganic nitrogen, $\mathrm{pH}$ and short chain fatty acids. As the reactor had already been commissioned on the distillery effluent, it was decided to evaluate the performance of the plant based on the COD removal efficiency.

The selected time taken to start-up for the different seasons are provided in Table 4. It can be seen that in 1998 and 1999, start-up, and thus, stable conditions were reached within the first week of operation. In contrast, the 2000 season required just over three weeks to reach similar conditions.

During the 1998 season the VLR applied to the plant during start-up was between 4 and $8 \mathrm{~kg} \mathrm{COD} / \mathrm{m}^{3} \cdot \mathrm{d}$. This is higher than the $3 \mathrm{~kg} \mathrm{COD} / \mathrm{m}^{3} \cdot \mathrm{d}$ loading rate recommended by Garcia-Bernet et al. (1998) for start-up. The plant was started-up within $8 \mathrm{~d}$ and the process remained stable even when the loading rates increased to $18 \mathrm{~kg} \mathrm{COD} / \mathrm{m}^{3} \cdot \mathrm{d}$.

The applied loading rate to the plant at start-up in the 1999 season was between 2 and $5 \mathrm{~kg} \mathrm{COD} / \mathrm{m}^{3} \cdot \mathrm{d}$. The plant was started up within $7 \mathrm{~d}$. There were two shutdowns and consequent start-ups (Table 2 and Fig. 6) and no drop in plant performance was observed. The plant was re-started within a day.

For the 2000 season the start-up period lasted $25 \mathrm{~d}$ (Fig. 7 and Table 4 ). When the 
reactor was started up the applied volumetric loading rates were between 3 and $6 \mathrm{~kg} \mathrm{COD} / \mathrm{m}^{3} \cdot \mathrm{d}$. During this period the removal efficiencies rapidly increased from $60 \%$ to above $90 \%$. However, after day 6 the VLR was increased from 3 to $12 \mathrm{~kg} \mathrm{COD} / \mathrm{m}^{3} \cdot \mathrm{d}$, which resulted in a sharp decrease in COD removal to as low as $65 \%$. For the next $19 \mathrm{~d}$ the applied loading rates were very erratic between 8 and $11 \mathrm{~kg}$ $\mathrm{COD} / \mathrm{m}^{3} \cdot \mathrm{d}$ and the COD removal efficiency varied between 65 and $90 \%$. The applied loading rate was then decreased to below $8 \mathrm{~kg} \mathrm{COD} / \mathrm{m}^{3} \cdot \mathrm{d}$, and during this period, the plant achieved operational stability. After operational stability was achieved, the VLR was increased to $18 \mathrm{~kg} \mathrm{COD/}$ $\mathrm{m}^{3} \cdot \mathrm{d}$ with no significant decrease in the COD removal efficiency. Alphenaar (1994) reported that should the loading rate applied during start-up be decreased and then abruptly increased prior to an equilibrium state being reached in the sludge bed, there is a possibility of a decrease in granule stability and, consequently, a decrease in reactor performance. Once a new equilibrium has been reached, the performance of the plant improves and stabilises. This can be noted in the fluctuating plant performance in relation to the sharply fluctuating loading rates at the beginning of the season. The plant was shut down once during this season, and for the second start-up the plant required less than a day to achieve high COD removal efficiencies.

After each season the reactor was allowed to stand filled with effluent until the next season. The reactor was shut down for a period of 10 months between the 1998 and 1999 seasons and for a period of 9 months between the 1999 and 2000 seasons. Even after such a lengthy period of inactivity, the reactor treated the full effluent load at removal efficiencies of greater than $90 \%$ within a few days. This compares well with the findings of Wolmarans and Nell (1997) where COD removal efficiencies of $90 \%$ were achieved in a pilot plant treating distillery effluent which was being operated on a stop-start basis.

\section{Conclusions and recommendations}

Volumetric loading rates of up to $18 \mathrm{~kg} \mathrm{COD} / \mathrm{m}^{3} \cdot \mathrm{d}$ were applied to the system without a decrease in the performance of the process $(+$ $90 \%$ removal). The UASB technology is well-suited for the pretreatment of high strength distillery effluents. It must be noted that this is only when the process has been successfully started up and is in stable operation.

In order to achieve a successful start-up, it is recommended that the reactor be started up at a low loading rate of between 4 and $8 \mathrm{~kg}$

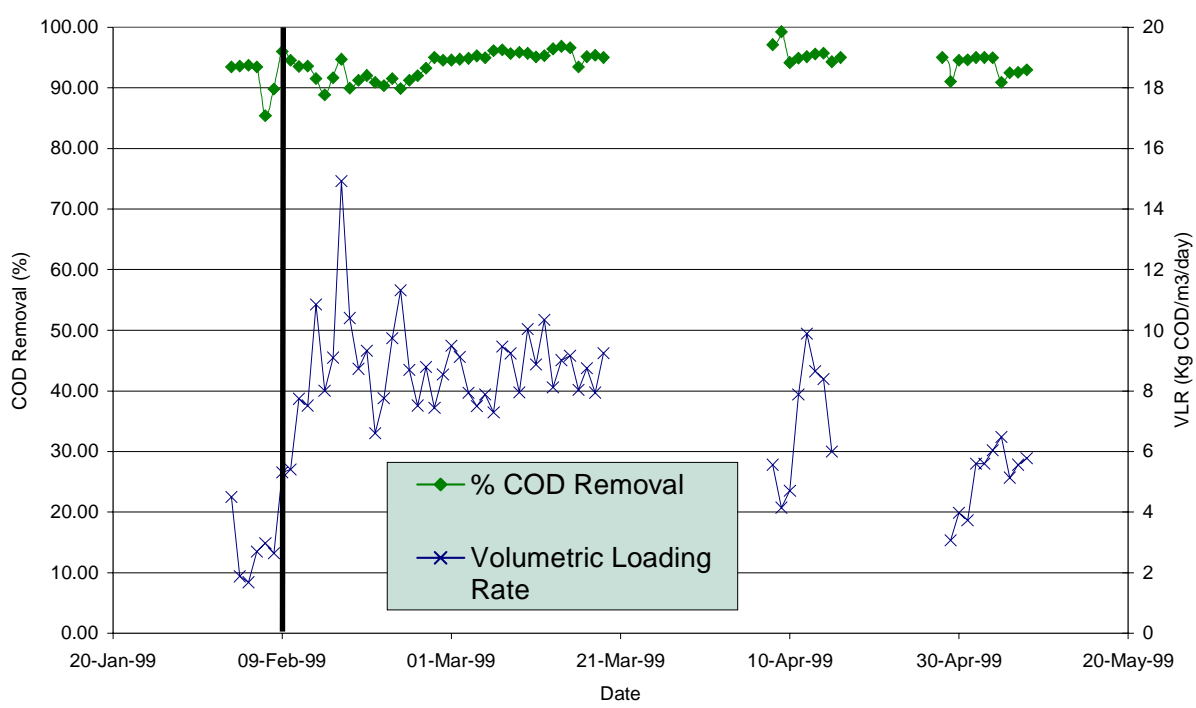

Figure 6

Percentage COD removal efficiency vs. volumetric loading rates for 1999

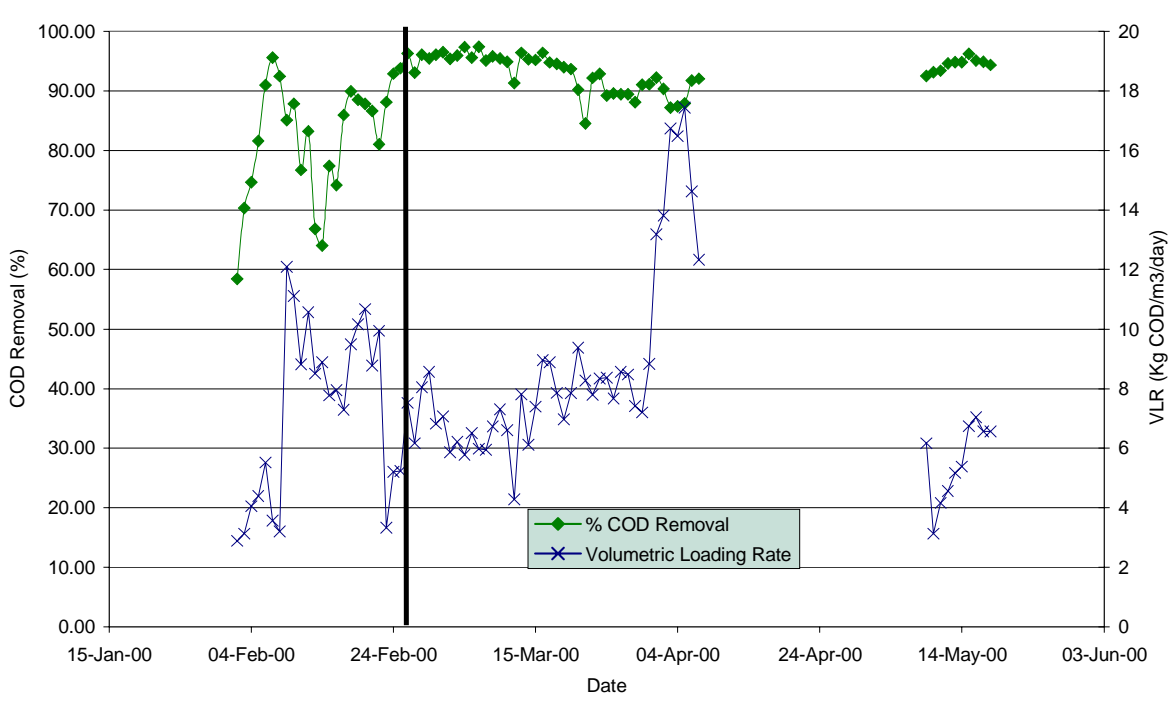

Figure 7

Fiency vs. volumetric loading rates for 2000

\begin{tabular}{|l|l|l|}
\hline \multicolumn{3}{|c|}{$\begin{array}{c}\text { TABLE 4 } \\
\text { Start-up period }\end{array}$} \\
\hline 1998 & 1999 & 2000 \\
\hline $\begin{array}{l}8 \mathrm{~d} \\
17 \text { to 24 February }\end{array}$ & $\begin{array}{l}7 \mathrm{~d} \\
3 \text { to } 9 \text { February }\end{array}$ & $\begin{array}{l}25 \mathrm{~d} \\
2 \text { to 26 February }\end{array}$ \\
\hline
\end{tabular}

$\mathrm{COD} / \mathrm{m}^{3} \cdot \mathrm{d}$ and the COD removal efficiency must be monitored carefully. Once the COD removal efficiencies are above $90 \%$ and remain there, then the loading rate can be increased.

To ensure low loading rates, either the production of the distillery must be planned such that the flow rate of the effluent stream be increased gradually, or sufficient effluent storage must be incorporated in the design to accommodate this. Attention must also be paid to the temperature, and high loading rates should not 
be applied until the temperature in the reactor has reached the recommended 34 to $36^{\circ} \mathrm{C}$. This is especially important in effluent streams that have low flow rates with correspondingly high COD concentrations such as distillery wastes. With sufficient control of these parameters, the first start-up of the season takes approximately one week and, should the plant be shutdown during the season, it can be started up within a day. Once the plant has been successfully started up, fluctuations in the volumetric loading rate do not significantly affect the performance of the reactor.

If COD analysis is performed on an unfiltered basis, then care must be taken while evaluating the performance of the plant. A high-treated effluent COD may not necessarily mean poor COD removals, and can be attributed to solids wash out from the reactor. It is recommended that COD samples of the influent be performed on an unfiltered basis and the treated effluent COD be performed on a filtered basis. The use of COD as process performance parameter on grape wine distillery effluent is possible due to the fact that the COD of the effluent is primarily organic acids and, thus, soluble biodegradable COD. Therefore, when measuring the $\mathrm{COD}$, in effect, the volatile fatty acids concentration is mainly being measured. This allows for easier plant operation as only COD is measured as opposed to COD, alkalinity and volatile fatty acids which is usually recommended.

\section{Acknowledgements}

The authors wish to thank Stellenbosch Farmers Winery for their assistance with this paper.

\section{References}

ALPHENAAR A (1994) Anaerobic Granular Sludge: Characterization and Factors Affecting its Functioning. Ph.D. Thesis, Agric. Univ. of Wageningen, The Netherlands. 61-72.

AUSTERMANN-HAUN U, SEYFRIED CF, KUNST S, BROCKMANN

M, BANZINGER W and ROSENWINKEL KH (1994) Anaerobic pretreatment in campaign industries. Proc. 7th Int. Symp. on Anaerobic Dig., Cape Town. 325-336.

DRIESSEN WJMB, TIELBAARD MH and VEREIJKEN TLFM (1994) Experience on anaerobic treatment of distillery effluent with the UASB process. Proc. 7th Int. Symp. on Anaerobic Dig., Cape Town. 253-262.

EREMEKTAR G, BABUNA GF and INCE O (1999) Fate of inert COD fractions in two-stage biological treatment of a strong wastewater. J. Environ. Sci. and Health, Part A Toxic/Hazardous Subst. and Environ. Eng. 34 (6) 1329-1340.

GARCIA-BERNET D, BUFFIERE P, ELMALEH S and MOLETTA R (1998) Application of the down-flow fluidized bed to the anaerobic treatment of wine distillery wastewater. Water Sci. Technol. 8 (9) 393-399.

GOODWIN JAS and STUART JB (1994) Anaerobic digestion of malt whiskey distillery pot ale using upflow anaerobic sludge blanket reactors. Bioresour. Technol. 49 (1) 75-81.

HICKEY RF, WU WM, VEIGA MC and JONES R (1991) Start-up, operation, monitoring and control of high-rate anaerobic treatment systems. Water Sci. Technol. 28 (8) 207-255.

MOOSBRUGGER RE, WENTZEL MC, EKAMA GA and MARAIS GvR (1993) Treatment of wine distillery waste in UASB systems feasibility, alkalinity requirements and $\mathrm{pH}$ control. Water Sci. Technol. 28 (2) 45-54.

RAJESHWARI KV, BALAKRISHNAN M, KANSAL A, KUSUM L and KISHORE VVN (2000) State-of-the-art of anaerobic digestion technology for industrial wastewater treatment. Renewable and Sustainable Energy Rev. 4 (2) 135-156.

STANDARD METHODS (1985) Standard Methods for the Examination of Water and Wastewater $\left(16^{\text {th }}\right.$ edn.) American Public Health Association, Washington DC, USA.

VANDER WESTHUIZEN A and PAKKIESC (1992) Anaerobic treatment of a chemical distillery effluent using the ADU (Anaerobic Digestion - Ultrafiltration) process. Proc. 3rd Anaerobic Dig. Symp., Pietermaritzburg. 181-189.

WOLMARANS B and NELL B (1997) Biopaq ${ }^{\circledR}$ UASB treatment of distillery effluent - from pilot to full scale at SFW Wellington, RSA. Proc. Saiche 97, $8^{\text {th }}$ Natl. Meet., Cape Town. 